\title{
Biological effects of the toxic algal bloom of February and March 1998 on the benthos of Wellington Harbour, New Zealand
}

\author{
Robert G. Wear* ${ }^{*}$ Jonathan P. A. Gardner \\ Island Bay Marine Laboratory, School of Biological Sciences, Victoria University of Wellington, PO Box 600, Wellington, \\ New Zealand
}

\begin{abstract}
Wellington Harbour is a large $\left(\sim 85 \mathrm{~km}^{2}\right)$, semi-enclosed temperate ecosystem. We used unpublished baseline data from 6 subtidal and 1 intertidal harbour stations to quantify the ecological effects of the naturally occurring toxic bloom of the naked dinoflagellate Karenia brevisulcata (Chang) G.Hansen \& Moestrup during February and March 1998. Species richness decreased at 6 stations and increased at 1 station, numbers of individuals decreased at 4 of 4 stations, species diversity decreased at 5 of 5 stations, evenness decreased at 2 and increased at 2 stations, and biomass decreased at 2 of 3 stations. These data indicate that the $K$. brevisulcata bloom of late summer 1998 resulted in a mass die-off of the subtidal benthic invertebrates over a large area of Wellington Harbour, as well as of the flora and fauna at 1 intertidal location studied. Four major phyla (echinoderms, molluscs, polychaetes and crustaceans) were equally affected by the bloom, although different species within each phylum were differentially affected (regardless of phylum, small and shallowburrowing individuals were most affected). Multivariate statistical analyses of these data identified 3 clusters composed of 4 subtidal stations which showed the highest level of impact by the bloom and were based on a spatial/environmental component (location in the northern harbour; greater depth; low current/wave energy) as well as a temporal component (pre- vs post-bloom). The remaining 3 subtidal stations were less affected by the bloom and each formed a separate cluster according to spatial/environmental rather than temporal effects. This event has permitted us to quantify, for the first time, the effects of a natural toxic bloom on a large-scale temperate harbour ecosystem and to relate the magnitude of these effects to the geographic and environmental properties of different locations within that ecosystem.
\end{abstract}

KEY WORDS: Toxic algal bloom · Karenia brevisulcata (Chang) G.Hansen \& Moestrup · Community die-off · Mass mortality · Community structure $\cdot$ Wellington Harbour · New Zealand

Resale or republication not permitted without written consent of the publisher

\section{INTRODUCTION}

During the period mid-February to late March 1998, an unprecedented build-up of the newly described species of naked dinoflagellate Karenia brevisulcata (Chang) G.Hansen \& Moestrup (see Daugbjerg et al. 2000) occurred in Wellington Harbour, New Zealand. This bloom resulted in widespread and almost total mortalities in the zooplankton, among pelagic and

*E-mail: bob.wear@vuw.ac.nz demersal fish species, and among epibenthic and benthic invertebrates over all trophic levels. Underwater video-records of areas in the northern harbour around Evans Bay and the Miramar Peninsula (see Fig. 1) showed large numbers of dead polychaetes, gastropod and bivalve molluscs, echinoderms, decapod crustaceans and fishes on the substrate. Normally deepburrowing polychaetes and bivalves had emerged from their burrows; subtidal invertebrates were moribund and had migrated into the low intertidal zone. Pelagic fishes were filmed swimming in disorientated spasms. In the 2 to $3 \mathrm{wk}$ following the peak of the 
bloom, large quantities of dead and dying shellfish, in particular the greenshell mussel Perna canaliculus and the venerid clam Paphies australis were washed up on Petone and eastern harbour beaches (see Fig. 1). This toxin (which is presently uncharacterised) also had a direct effect on microalgal growth in the water column (Chang 1998), and during SCUBA observations of the substrate at 5 to $10 \mathrm{~m}$ depth we noted that the sediments were coated with a khaki- coloured film and that there was no evidence of recent bioturbation. This was the first time that an algal bloom in Wellington Harbour had been linked to mass destruction of the marine fauna, and is the first quantitative record of the direct effect of a natural toxic algal bloom upon the benthic invertebrates of a large $\left(\sim 85 \mathrm{~km}^{2}\right)$ temperate marine ecosystem.

The sequence of events leading up to the bloom and during its period of influence was documented by Chang (1998). The Wellington Harbour bloom followed earlier reports of mortalities among fish and other marine fauna along the southern North Island east coast during January and February 1998, and has been attributed to the effects of the early phase of La Niña weather pattern (Chang 1999b). Coastal waters of the area became 2 to $3^{\circ} \mathrm{C}$ warmer than usual, and pronounced stratification of the water column contributed to a peak bloom in mid-March of over $33 \times$ $10^{6}$ cells l $^{-1}$ in the nutrient-rich harbour waters (Chang 1998).

We possess unpublished quantitative or semi-quantitative data from 6 subtidal and 1 intertidal localities in Wellington Harbour, all obtained within the $9 \mathrm{yr}$ period prior to the toxic algal bloom. We therefore have the unusual luxury (Warwick 1993) of a pre-bloom baseline data set from each of 7 sites prior to the incident. It was not possible to sample from a genuine control site because the bloom affected all previously sampled areas within Wellington Harbour, and sites outside the harbour on the open coast differ greatly in their ecology. Despite this, we are able to quantify the effects of the toxic bloom upon the benthos of a large-scale temperate marine ecosystem. In the present paper we record the impacts of the bloom on the benthos of Wellington Harbour by comparing the baseline data set with a data set collected at the same 7 locations immediately post-bloom. To the best of our knowledge, this is only the second time that such a comparison has been made between pre- and post-bloom data, and it therefore represents a rare opportunity to record and quantify the biological effects of a natural toxic algal bloom. The only other published report of the effects of a natural toxic algal bloom that we are aware of relates to a large die-off due to the red tide organism Gymnodinium breve during the summer of 1971 at Tampa Bay, west coast of Florida (Simon \& Dauer 1977). The
Florida die-off did not result from the direct effects of the toxic bloom itself, but indirectly from anaerobic conditions arising from large accumulations of dead fishes. This impacted site was small $(2.5 \times 0.12 \mathrm{~km})$, and is described as a subtropical, intertidal estuarine environment (Simon \& Dauer 1977).

By comparison, the present study reports findings from a large-scale harbour basin $(11 \times 8 \mathrm{~km})$ in the temperate zone, with affected areas being both subtidal and intertidal. This is therefore a unique opportunity to document the impact of a large-scale natural toxic algal bloom. Because the impact of such an event has not been quantified previously, we are in effect testing the null hypothesis that such a bloom has no significant effect upon the biota of a large semienclosed temperate marine ecosystem, as measured in terms of species richness $(S)$, numbers of individuals $(N)$, species diversity $\left(H^{\prime}\right)$, evenness $(E)$, and biomass (B). The expectation, if the null hypothesis is false, is that $N, S, H^{\prime}$ and $B$ will all decrease at stations where the bloom has an impact. $E$ does not necessarily have to decrease because it is a function of $H^{\prime}$ and $S$. Its response is dictated by how the relative composition of the community changes in response to the bloom.

\section{MATERIALS AND METHODS}

Physical setting, hydrology and sediments. Wellington Harbour is located at the southern tip of the North Island of New Zealand ( $41^{\circ} 16^{\prime} \mathrm{S}, 174^{\circ} 51^{\prime} \mathrm{E}$ : Fig. 1). It is a roughly circular basin, $85 \mathrm{~km}^{2}$ in area (Heath 1977), with a single entrance leading south to Cook Strait. Mean water depth within the harbour is $\sim 14 \mathrm{~m}$ with a maximum depth of $31 \mathrm{~m}$ to the southeast of Matiu/Somes Island (Heath 1977). Tides are semidiurnal and of small amplitude (0.9 to $1.2 \mathrm{~m}$ ), and mean tidal exchange is $60 \times 10^{6} \mathrm{~m}^{3}$ or $4.5 \%$ of the total harbour volume (Maxwell 1956), giving a calculated residence time of about $11 \mathrm{~d}$. The major freshwater inflow is from the Hutt River which discharges between 2.6 and $180 \times 10^{6} \mathrm{~m}^{3} \mathrm{~d}^{-1}$ at the northeast corner of the harbour (Maxwell 1956). Freshwater input during floods is generally confined to $\leq 5 \mathrm{~m}$ and the harbour waters are usually well mixed (Booth 1975). Sediments are mostly clay, silt and sand with shell fragments (Carter \& Lewis 1995). Harbour basin sediment in depths $>10 \mathrm{~m}$ is a uniformly deep layer of $>90 \%$ silt (phi $>4.0$ ) with an organic carbon content of $\sim 6 \%$ (Wear \& Anderlini 1995) primarily derived from the Hutt River (van der Linden 1967). The relatively shallow entrance area, northern and eastern beaches and Oriental Bay in the inner harbour (Fig. 1) are areas of mainly sand in the 2.2 to 3.4 phi range (Carter \& Mitchell 1985, Carter \& Lewis 1995). 


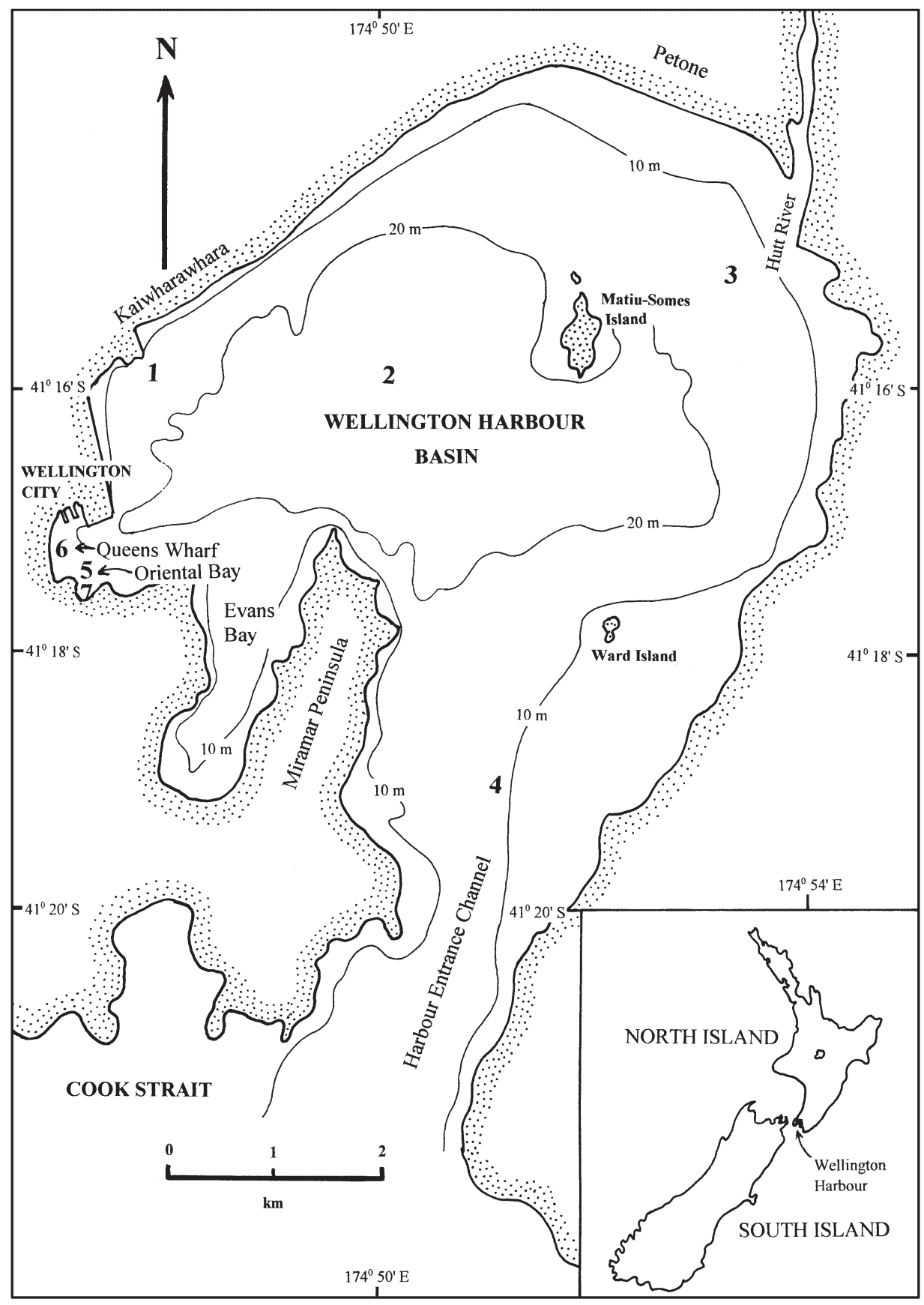

Fig. 1. Map of Wellington Harbour, showing 7 sampling stations and other locations mentioned in the text. Stns 1 to 7 are Kaiwharawhara, Harbour Basin West, Harbour Basin East, Entrance Channel, Oriental Bay (subtidal), Queens Wharf and Oriental Bay (intertidal), respectively

Location of stations and sample collection. Study areas were located according to contract research requirements relating to proposals for dredging, sediment disposal or pipeline construction. As such the stations are 'historical accidents', and although not distributed in any systematic manner (Fig. 1) provide a reasonably good coverage of different habitat types and energy environments in the harbour (Fig. 1). All are located in areas over which the existing benthos was to be disturbed, smothered or removed by sediment deposition or by dredging, none of which has yet occurred. The benthic study areas and stations within them were originally located using GPS or by radar and/or landmark configuration and ship-to-shore 
theodolite fixing using 1:50 000 New Zealand Hydrographic Chart No. 4633. No studies carried out prior to 1989 were used as the pre-bloom baseline. Post-bloom stations were relocated using differential GPS with a nominal accuracy of $\pm 2.0 \mathrm{~m}$. In all pre- and post-bloom grab sampling, the same $0.1 \mathrm{~m}^{2}$ van Veen grab was used. Study areas and stations are illustrated in Fig. 1.

Stn 1: An area of $\sim 50 \mathrm{~m}$ radius centred around $41^{\circ} 15.88^{\prime} \mathrm{S}, 174^{\circ} 47.58^{\prime} \mathrm{E}$ in the northwest part of the harbour from which a single grab sample was taken from each of 5 locations (i.e. 5 pre-bloom replicates) at a depth of $14 \mathrm{~m}$ below chart datum (CD) (Wear \& Anderlini 1995). For post-bloom study, Location 5 of Wear \& Anderlini (1995) at $41^{\circ} 15.88^{\prime} \mathrm{S}, 174^{\circ} 47.60^{\prime} \mathrm{E}$ was selected at random and 5 replicate samples were collected from this station on 6 May 1998. Substrate type at this station is soft mud with recently (up to 1984) dumped aggregate yielding samples of $\geq 8 \mathrm{l}$ from a minimum substrate depth of $80 \mathrm{~mm}$.

Stn 2: A $200 \mathrm{~m} \times 200 \mathrm{~m}$ box containing 5 locations, centred around $41^{\circ} 15.80^{\prime} \mathrm{S}, 174^{\circ} 50.00^{\prime} \mathrm{E}$ near the centre of the harbour basin at $20 \mathrm{~m} \mathrm{CD}$, from each of which 1 grab sample was taken (Wear \& Anderlini (1995). Five post-bloom replicate samples were collected on 6 May 1998, from Location 3 of Wear \& Anderlini at $41^{\circ} 15.85^{\prime} \mathrm{S}, 174^{\circ} 50.02^{\prime} \mathrm{E}$ which was randomly selected for post-bloom study. Substrate type at this station is soft mud, and sample volume was $20 \mathrm{l}$ from a substrate depth of $200 \mathrm{~mm}$.

Stn 3: Pre-bloom and post-bloom Stn 3 was selected from a series of 7 approximately equally spaced locations between the Hutt River mouth and the southern end of Matiu/Somes Island (Wear et al. (1990). This station (Location 4 of the original study), at $41^{\circ} 15.20^{\prime} \mathrm{S}$, $174^{\circ} 53.35^{\prime} \mathrm{E}$, is remote from the constant influence of the Hutt River and permanent aquifers, and is situated at $15 \mathrm{~m}$ CD making it comparable to other locations. At this location, 1 core sample (total core area $=0.04 \mathrm{~m}^{2}$ ) was taken pre-bloom from a single grab sample. Thus, we do not have pre-bloom replicates from this station, and our 1 pre-bloom sample is of smaller volume than samples from other stations (one sample of $0.04 \mathrm{~m}^{2} \mathrm{vs}$ 5 replicates of $0.1 \mathrm{~m}^{2}$ from other stations). Five replicate samples were collected from this post-bloom station on 5 May 1998. Substrate type at this station is soft mud, and sample volume was $20 \mathrm{l}$ from a substrate depth of $200 \mathrm{~mm}$.

Stn 4: Five locations (1 sample per location) over an area of $400 \times 75 \mathrm{~m}$ in the harbour entrance centred at $41^{\circ} 19.04^{\prime} \mathrm{S}, 174^{\circ} 51.24^{\prime} \mathrm{E}$ (Location 25 of Haddon \& Wear 1993) ranging from 9.5 to $2.3 \mathrm{~m} \mathrm{CD}$. Five replicate post-bloom samples were taken from location 25 $\left(41^{\circ} 19.04^{\prime} \mathrm{S}, 174^{\circ} 51.24^{\prime} \mathrm{E}\right)$ in $11.3 \mathrm{~m} \mathrm{CD}$ on 19 May 1998. This location was randomly selected from the pre- bloom locations for post-bloom study. Substrate type is relatively mobile fine to medium sand, yielding samples of $\sim 10 \mathrm{l}$ from a minimum substrate depth of $100 \mathrm{~mm}$.

Stn 5: Five $80 \mathrm{~m}$ transects, 60 to $100 \mathrm{~m}$ apart, extending from extreme low-water springs (ELWS) to $\sim 2.0 \mathrm{~m}$ $\mathrm{CD}$ in Oriental Bay, an inner city beach in the western part of the harbour. One benthic sample $(500 \times 250 \mathrm{~mm}$ quadrat) to a substrate depth of $\sim 100 \mathrm{~mm}$ was excavated by divers at the seaward end of each transect providing 5 pre-bloom replicates (Wear 1997a,b). The seaward end of the centre transect $\left(41^{\circ} 17.51^{\prime} \mathrm{S}\right.$, $174^{\circ} 47.70^{\prime} \mathrm{E}$ in $1.8 \mathrm{~m} \mathrm{CD}$ ) was chosen for post-bloom comparison. Five replicate $500 \times 250 \mathrm{~mm}$ samples to a substrate depth of $\sim 100 \mathrm{~mm}$ were excavated by divers on 8 May 1998. Substrate type is coarse compacted sand.

Stn 6: Five locations (1 grab sample per location) along a north-south axis (from $41^{\circ} 17.27^{\prime} \mathrm{S}, 174^{\circ} 46.82^{\prime} \mathrm{E}$ to $\left.41^{\circ} 17.36^{\prime} \mathrm{S}, 174^{\circ} 46.84^{\prime} \mathrm{E}\right) \sim 170 \mathrm{~m}$ in length adjacent to Queens Wharf in the inner city port area (Anderlini \& Wear 1995) were sampled pre-bloom. Location 3 of the pre-bloom study (at $41^{\circ} 17.35^{\prime} \mathrm{S}, 174^{\circ} 46.80^{\prime} \mathrm{E}$ in $9.0 \mathrm{~m} \mathrm{CD}$ ) was randomly selected for post-bloom comparison. Five replicate samples were collected from this station on 8 May 1998. Substrate type at this station is soft mud, and sample volume was $20 \mathrm{l}$ from a substrate depth of $200 \mathrm{~mm}$.

Stn 7: One intertidal $2 \mathrm{~m}$ wide strip-transect (Wear 1997a) from extreme high-water springs (EHWS) to ELWS in Oriental Bay, located at $41^{\circ} 17.56^{\prime} \mathrm{S}$, $174^{\circ} 47.73^{\prime} \mathrm{E}$. The transect was stratified according to tidal height into high-shore (the vertical rock face containing the barnacle and littorinid zones), mid-shore (principally the blue mussel Mytilus galloprovincialis zone), the low-shore (the area below the mussel zone). Within each stratum, 3 replicate $250 \times 250 \mathrm{~mm}$ quadrats were randomly located and all biota were recorded using a semi-quantitative scale of abundance (see 'Materials and methods' for details). The highshore comprised a vertical concrete protective sea wall, and the mid- and low-shores were an $\sim 18 \mathrm{~m}$ wide beach of angular cobbles, phi sizes -6 to -7 ( 64 to $256 \mathrm{~mm}$ diameter), with occasional boulders of phi size $-8(>256 \mathrm{~mm})$. The beach is exposed to prevailing winds from the northerly quarter (Fig. 1). The postbloom station location and sampling methodology were the same as for the pre-bloom situation. Semiquantitative intertidal data were obtained from the high-, mid- and low-shore levels. At each tide level the relative abundance of the macrofauna was calculated from 3 randomly placed $250 \times 250 \mathrm{~mm}$ quadrats within which the surface organisms and those living beneath cobbles were counted and their maximum abundances recorded as abundant $\left(>1000 \mathrm{~m}^{-2}\right)$, very common $(1000$ 
to $100 \mathrm{~m}^{-2}$ ), common (99 to $10 \mathrm{~m}^{-2}$ ), few $\left(9\right.$ to $1 \mathrm{~m}^{-2}$ ) or absent. Macroalgae were recorded as present or absent. Post-bloom data were recorded on 28 May 1998 in the same manner as pre-bloom data.

Pre-bloom samples from Stns 1, 2, 3, 4, 5, and 7 were collected during the austral summer to early fall (December to March), whereas pre-bloom samples from Stn 6 were collected in mid-winter (July 1995).

Laboratory methods. Pre- and post-bloom samples for biological analysis were sieved to $0.75 \mathrm{~mm}$, fixed in $10 \%$ formalin solution for $3 \mathrm{~d}$, then preserved in $70 \%$ ethanol. Sievings were spread thinly over a white plastic tray and all animals were picked out prior to identification, counting and weighing to 4 decimal places (dp).

For post-bloom study, a subsample of $250 \mathrm{~g}$ was removed from each bulk sample (ensuring that no organisms were present) for sediment and organic carbon content analyses. Sediment samples were homogenised, subsampled to $\sim 100 \mathrm{~g}$, oven-dried to constant weight, then rehydrated and wet-sieved through an Endecott series to a lower limit of $0.063 \mathrm{~mm}$. The fractions were re-dried at $60^{\circ} \mathrm{C}$ before weighing to an accuracy of $4 \mathrm{dp}$ to permit calculation of median phi values. For organic matter determination, a sample of 25 g was placed in an aluminium container preweighed to $0.0001 \mathrm{~g}$ accuracy, then ashed in a muffle furnace at $500^{\circ} \mathrm{C}$ for $30 \mathrm{~h}$ before re-weighing.

Species identifications. Identifications were based on published and unpublished literature for Wellington Harbour and New Zealand (for many taxa this meant to family level only), or were based on 'morphospecies' (morphologically distinct individuals were considered to be different species). Unidentified species were listed as, for example, Maldanidae sp. A, sp. $B$, etc. For each pre-bloom study we had retained a reference collection. These were integrated with our post-bloom collections for species identifications, so we can be sure that we have consistently given each species the same name across all samples, both pre- and post-bloom. There was only a small number of refer- ence collection specimens for which this was not possible (specimens were lost, dried out or damaged), and based upon our knowledge of the marine ecology of Wellington Harbour we assigned 12 pre-bloom species to what we considered to be the most likely post-bloom taxon (i.e., 1 polychaete, 1 amphipod, 1 cumacean and 1 isopod for Stn 1; 1 isopod for Stn 2; 5 polychaetes for Stn $4 ; 1$ polychaete and 1 nemertean for Stn 5). At Stn 4, pre-bloom data for amphipods had been pooled into a single category 'amphipods' without species identifications. However, post-bloom identifications for this station were taken to species level.

Species-area curves per station. For 5 subtidal pre-bloom and all 6 subtidal post-bloom stations for which we had replicate samples we plotted speciesarea curves (cumulative numbers of species as a function of number of replicates) to estimate the proportion of species our sampling effort had recovered. Such curves describe a curvilinear function which reaches an asymptote, at which point extra samples are not adding new (previously unsampled) species to the species list for a station. We considered that a value of $\sim 90 \%$ of the asymptote provided adequate coverage for each station at any time.

Analytical methods. Baseline pre-bloom data relating to each station vary in accordance with the quality of the information required when carried out. These biological data are summarised in Table 1. For the 6 subtidal pre-bloom stations, species richness $(S)$, numbers of individuals $(N)$, species diversity $\left(H^{\prime}\right)$, evenness (the equitability index, $E$ ), and wet weight biomass $(B)$ were calculated in most cases. For the 6 subtidal postbloom stations all 4 parameters were determined. Species richness was obtained by recording the number of different species present in each sample. Species diversity was calculated according to the ShannonWiener index, and evenness was derived therefrom. $S, N$ and $B$ were also calculated for 4 major phyla (polychaetes, molluscs, crustaceans and echinoderms) for all stations except Stn 3 pre-bloom.

Table 1. Biological data from each of 7 stations for pre-bloom and post-bloom comparisons. $\sqrt{ }$ : available; $\mathrm{x}$ : not available; ${ }^{*}$ : all amphipod species pooled as one; ${ }^{* *}$ : relative abundance data only

\begin{tabular}{|c|c|c|c|c|c|}
\hline Stns & $\begin{array}{l}\text { Pre-/post- } \\
\text { bloom }\end{array}$ & $\begin{array}{c}\text { No. of } \\
\text { species }(S)\end{array}$ & $\begin{array}{c}\text { No. of } \\
\text { individuals }(N)\end{array}$ & $\begin{array}{c}\text { Biomass for } \\
\text { each species }(B)\end{array}$ & $\begin{array}{l}\text { Biomass for } \\
\text { all species }(B)\end{array}$ \\
\hline 1: Kaiwharawhara & Pre & $\sqrt{ }$ & $\sqrt{ }$ & $\mathrm{x}$ & $\sqrt{ }$ \\
\hline 2: Harbour Basin West & Pre & $\sqrt{ }$ & $\sqrt{ }$ & $\mathrm{x}$ & $\sqrt{ }$ \\
\hline 3: Harbour Basin East & Pre & $\sqrt{ }$ & $\mathrm{x}$ & $\mathrm{x}$ & $\mathrm{x}$ \\
\hline 4: Entrance Channel & Pre & $\sqrt{ } *$ & $\sqrt{ }$ & $\mathrm{x}$ & $\mathrm{x}$ \\
\hline 5: Oriental Bay (subtidal) & Pre & $\sqrt{ }$ & $\mathrm{x}$ & $\mathrm{x}$ & $\mathrm{x}$ \\
\hline 6: Queens Wharf & Pre & $\sqrt{ }$ & $\sqrt{ }$ & $\mathrm{x}$ & $\sqrt{ }$ \\
\hline Stns $1,2,3,4,5$ and 6 combined & Post & $\sqrt{ }$ & $\sqrt{ }$ & $\sqrt{ }$ & $\sqrt{ }$ \\
\hline 7: Oriental Bay (intertidal) & Pre and Post & $\sqrt{ }$ & $\mathrm{x}^{* *}$ & $\mathrm{x}$ & $\mathrm{x}$ \\
\hline
\end{tabular}


Data were analysed using the software package PRIMER (Plymouth Routines in Marine Ecological Research, Carr 1996). Unless otherwise stated, recommendations for statistical analyses in Clarke \& Warwick (1994) were followed. Where possible, estimates of $S_{1} H^{\prime}$ and $E$ were obtained for each replicate to permit calculation of a mean \pm SD for each station, both pre- and postbloom. Student's $t$-test comparisons of means \pm SD (small sample sizes, variances not assumed to be equal) of values were carried out for pre- versus post-bloom data at Stns 1, 2, 4, 5 and 6. For Stn 3 there were no pre-bloom replicates from which to calculate means \pm SD. We therefore used a small-sample $t$-test to determine if the prebloom individual sample values were significantly different from the mean \pm SD of the corresponding post-bloom index values. For all other analyses we used abundance $(N)$ data in preference to biomass $(B)$ data because the former was much more complete. We note that 'In practice, multivariate analyses of abundance and biomass give remarkably similar results ...' (Clarke \& Warwick 1994, p. 13-6). We used the complementary PRIMER routines CLUSTER and MDS (non-metric multi-dimensional scaling) to generate dendrograms and ordinations of abundance data for pre- and post-bloom stations. To minimise the effect of rarely occurring species, we excluded from the CLUSTER and MDS analyses all species for which only 1 individual was observed at all pre- and post-bloom stations (this reduced the species list from 171 to 132). For CLUSTER and MDS analyses we used $\log _{\mathrm{e}}(1+x)$ transformed abundance data because this produced a less severe transform for small abundance values than, for example, the 4 th root transformation (Clarke \& Warwick 1994). For all analyses, there was, however, very little difference in results for a range of transformations (square root, 4 th root, $\log _{\mathrm{e}}(1+x)$ and, to a lesser extent, presence/absence). For Stn 4 we did not have data for the numbers of amphipod species for the pre-bloom sampling. However, we performed all appropriate analyses with and without amphipod species included for all sites, pre- and postbloom, to determine the effect that this omission had upon the results. For all analyses the absence of amphipod species from pre-bloom Stn 4 when such species were included for all other pre- and post-bloom stations, or the exclusion of all amphipod species from all pre- and post-bloom stations, made no substantive difference. Thus, although individual amphipod species were not identified from pre-bloom Stn 4 we are confident that this had little or no effect upon the results.

For the intertidal location (Stn 7), relative abundance data from all 3 tide levels were pooled, and pre-bloom and post-bloom differences were calculated from presence/absence data using Jaccard's coefficient of association (see Sokal \& Sneath 1963). For both pre- and post-bloom, absolute abundance data and biomass data were unavailable. For the macrofauna, we assigned an arbitrary score to each of the 4 relative abundance categories (abundant $=4$, very common $=$ 3 , common $=2$, few $=1$ ) and then calculated the total abundance score for all categories. We used a $\chi^{2}$-test to determine if total pre-bloom score was significantly different from total post-bloom score, based on the assumption of expected pre- and post-bloom scores being equal. We also used a contingency $\chi^{2}$ analysis to test the numbers of macrofaunal species for each of the 4 abundance categories to determine if the bloom had effected the relative proportions of species per category. This allowed us to examine if, and how, the total abundance score for all species had changed between pre- and post- bloom surveys.

\section{RESULTS}

\section{Subtidal stations}

Species - area curves per station

For the 5 pre-bloom and the 6 post-bloom subtidal stations the number of species recovered was $\geq 95 \%$ of the asymptote of the sampling effort curve (Table 2). Curve fit, as judged by the coefficient of determination, was very high ( 0.99) in all cases. Thus, we can be confident that our use of 5 replicates per station provides sufficient sampling coverage for us to have observed most, if not all, of the species present in the pre-bloom and immediate post-bloom environments.

\section{Species richness $(S)$}

$S$ decreased significantly pre- versus post-bloom at Stns 1, 2, 3 and 6, increased significantly at Stn 5, and was not significantly different at Stn 4 (Table 3). Mean $S$ for the 4 stations with 20 pre- and 20 post-bloom replicates (Stns 1, 2, 4 and 6) decreased significantly from $18.800 \pm 6.170$ to $11.650 \pm 6.352(t=3.611, \mathrm{df}=38$, $\mathrm{p}<0.001$ ), even though there were no amphipod species in the pre- bloom data for Stn 4, and 9 amphipod species were present at this station post-bloom. When assessed at the level of phylum, $S$ (standardised to per $0.1 \mathrm{~m}^{-2}$ grab) typically decreased from pre- to postbloom (Table 4). The magnitude of these changes varied from station to station, and from phylum to phylum, but the changes were relatively consistent among major phyla. $S$ for the polychaetes and molluscs decreased at 5 of 6 stations, and for the echinoderms and crustaceans it decreased at 4 of 6 stations. Among these 4 main phyla, the only 2 stations to exhibit an increase in $S$ were Stns 4 and 5. 
Numbers of individuals $(N)$

$N$ per station decreased significantly pre- versus post-bloom at Stns 2 and 6, and was not significantly different at Stns 1 and 4 (Table 3). Sample variability increased 4 -fold at Stn 1, but remained unchanged at Stn 4 . Mean $N$ values for the 4 stations with 20 preand 20 post-bloom replicates (Stns 1, 2, 4 and 6) were not significantly different at $91.250 \pm 75.672$ and $61.650 \pm 73.269$ respectively $(t=1.257, \mathrm{df}=38, \mathrm{p}>$ 0.05). When assessed at the phylum level, numbers of individuals typically decreased for all major groups with the exception of the crustaceans (Table 4). The polychaetes and echinoderms decreased at 4 of 4 stations, and the molluscs decreased at 3 of 4 stations. In contrast, the crustaceans increased at 3 of 4 stations.

\section{Species diversity $\left(H^{\prime}\right)$}

$H^{\prime}$ decreased significantly pre- versus post-bloom at Stns 1, 2, 3 and 6, and was not significantly different at Stn 4 (Table 3). Mean $H^{\prime}$ for the 4 stations with 20 preand 20 post-bloom replicate samples (Stns 1, 2, 4 and 6) decreased from $2.268 \pm 0.442$ to $1.792 \pm 0.473(t=$ 3.288 , df $=38, \mathrm{p}<0.001)$.

\section{Evenness $(E)$}

E remained unchanged pre- vs post-bloom at Stns 1, 4 and 6 , and increased significantly at Stns 2 and 3 (Table 3). Mean $E$ values for the 4 stations with 20 preand 20 post-bloom replicate samples (Stns 1, 2, 4 and 6) remained unchanged at $0.788 \pm 0.125$ and $0.806 \pm$ $0.164(t=0.390, \mathrm{df}=38, \mathrm{p}>0.05)$.

Table 2. Number of species, asymptote values and coefficients of determination (CD) for the species - area curves, pre- and post-bloom

\begin{tabular}{|llccc|}
\hline Stn & $\begin{array}{c}\text { Pre-/post- } \\
\text { bloom }\end{array}$ & $\begin{array}{c}\text { Total no. } \\
\text { of species } \\
\text { observed }\end{array}$ & $\begin{array}{c}\text { Asymptote } \\
\text { of curve }\end{array}$ & $\begin{array}{c}\text { Coefficient of } \\
\text { determination } \\
\text { of curve }\end{array}$ \\
\hline 1: Kaiwharawhara & Pre & 51 & 50.344 & 0.997 \\
2: Harbour Basin West & Post & 36 & 36.470 & 0.999 \\
& Pre & 30 & 29.098 & 0.992 \\
3: Harbour Basin East & Post & 13 & 12.695 & 0.992 \\
4: Entrance Channel & Post & 8 & 8.067 & 0.999 \\
& Pre & 52 & 48.621 & 0.997 \\
5: Oriental Bay & Post & 49 & 51.309 & 0.999 \\
6: Queens Wharf & Pre & 18 & 17.312 & 0.990 \\
& Post & 35 & 34.504 & 0.998 \\
& Pre & 35 & 32.285 & 0.993 \\
& Post & 16 & 16.402 & 0.998 \\
\hline
\end{tabular}

Biomass (B)

$B$ remained unchanged pre- versus post-bloom at Stns 2 and 6, but decreased significantly at Stn 1 (Table 3). High variability in pre-bloom $B$ at Stn 2 $(32.368 \pm 48.299 \mathrm{~g})$ obscured the 5 -fold decrease in mean post-bloom $B(6.539 \pm 7.729 \mathrm{~g})$. The pre-bloom data do not contain estimates of $B$ per phylum, so no pre-bloom versus post-bloom comparisons at this taxonomic level can be made.

Table 5 provides a summary of the station-by-station responses for each of the 5 biological indices to the effects of the bloom. As expected, the overwhelming response is one of decrease: 20 of 25 measurements were decreases, with 15 of these being statistically significant.

\section{Cluster analysis}

The dendrogram for pre- and post-bloom samples showed the existence of 5 major clusters (Fig. 2). Cluster I was composed of all 15 pre-bloom replicates from Stns 1, 2 and 6, with replicates from Stn 6 being somewhat distinct from those of Stns 1 and 2 . Cluster II was composed of all 10 post-bloom replicates from Stns 1 and 2 ( 20\% similarity), while Cluster III was composed of all 10 post-bloom replicates from Stns 3 and 6 ( 20\% similarity). Cluster IV was composed of 5 post-bloom replicates from Stn 5 ( $45 \%$ similarity). Cluster $\mathrm{V}$ was composed of all 5 pre-bloom replicates from Stn 4 ( $57 \%$ similarity) and all 5 post-bloom replicates from this Stn $(\sim 52 \%$ similarity).

\section{MDS analysis}

At the $20 \%$ level of similarity (dashed line in Fig. 3) 5 discrete groupings were apparent (I: the prebloom replicates of Stns 1, 2 and 6; II: the post-bloom replicates of Stns 1 and 2 ; III: the post-bloom replicates of Stns 3 and 6; IV: the post-bloom replicates from Stn 5; and V: pre- and postbloom samples for Stn 4 ). At the $40 \%$ level of similarity (continuous line in Fig. 3), Cluster I was divisible into 3 separate groupings, each being composed of the 3 separate stations $(1,2$ and 6). Cluster II was broadly divisible into 2 separate groupings (Stns 1 and 2), and Cluster III was less clearly divisible, although there was a ten- 
Table 3. Student's $t$-test comparisons of mean \pm SD values for species richness $(S)$, numbers of individuals $(N)$, species diversity $\left(H^{\prime}\right)$, evenness $(E)$, biomass $(B)$, percent organic matter of sediment $(\% O M)$ and sediment median phi size $(\Phi)$ for pre-bloom versus post-bloom stations. - : no data; ns: $\mathrm{p}>0.05,{ }^{*} \mathrm{p}<0.05,{ }^{* *} \mathrm{p}<0.01,{ }^{* * *} \mathrm{p}<0.001$

\begin{tabular}{|c|c|c|c|c|c|}
\hline $\begin{array}{l}\text { Stn, } \\
\text { Index }\end{array}$ & $\begin{array}{l}\text { Pre-bloom } \\
\text { mean (SD) }\end{array}$ & $\begin{array}{c}\text { Post-bloom } \\
\text { mean (SD) }\end{array}$ & $t$-test & $\mathrm{df}$ & $\mathrm{p}$ \\
\hline \multicolumn{6}{|c|}{ 1: Kaiwharawhara } \\
\hline$S$ & $23.600(5.595)$ & $15.400(2.074)$ & 3.073 & 8 & $* *$ \\
\hline$N$ & $61.600(9.317)$ & 49.200 (42.617) & 0.636 & 8 & ns \\
\hline$H^{\prime}$ & $2.852(0.270)$ & $2.312(0.452)$ & 2.293 & 8 & * \\
\hline$E$ & $0.908(0.033)$ & $0.851(0.176)$ & 0.712 & 8 & ns \\
\hline$B$ & $14.468(6.640)$ & $5.932(2.453)$ & 2.696 & 8 & ** \\
\hline$\% O M$ & $6.100(1.654)$ & $5.627(2.259)$ & 0.349 & 7 & ns \\
\hline$\Phi$ & $2.660(1.476)$ & $0.140(2.071)$ & 2.216 & 8 & ${ }^{*}$ \\
\hline \multicolumn{6}{|c|}{ 2: Harbour Basin West } \\
\hline$S$ & $14.600(3.578)$ & $6.200(2.280)$ & 4.427 & 8 & ${ }^{* *}$ \\
\hline$N$ & $59.600(18.488)$ & $13.400(9.864)$ & 4.930 & 8 & ${ }^{* * *}$ \\
\hline$S$ & $23.600(5.595)$ & $15.400(2.074)$ & 3.073 & 8 & ${ }^{* *}$ \\
\hline$H^{\prime}$ & $2.000(0.323)$ & $1.584(0.349)$ & 1.956 & 8 & $*$ \\
\hline$E$ & $0.752(0.071)$ & $0.898(0.075)$ & 3.161 & 8 & $* *$ \\
\hline$B$ & $32.368(48.299)$ & $6.539(7.729)$ & 1.181 & 8 & ns \\
\hline$\% O M$ & $5.398(1.018)$ & $5.870(0.196)$ & 1.018 & 8 & ns \\
\hline$\Phi$ & $4.060(0.207)$ & $4.480(0.045)$ & 4.433 & 8 & $* * *$ \\
\hline \multicolumn{6}{|c|}{ 3: Harbour Basin East } \\
\hline$S$ & $17.000^{\mathrm{a}}$ & $3.600(0.894)$ & 33.517 & 4 & *** \\
\hline$N$ & - & $4.800(2.168)$ & - & & - \\
\hline$H^{\prime}$ & $2.540^{\mathrm{a}}$ & $1.212(0.191)$ & 15.547 & 4 & *** \\
\hline$E$ & $0.896^{\mathrm{a}}$ & $0.967(0.032)$ & 4.961 & 4 & *** \\
\hline$B$ & - & $2.371(3.453)$ & - & - & - \\
\hline$\% O M$ & $4.400^{\mathrm{a}}$ & $7.220(0.341)$ & 18.492 & 4 & *** \\
\hline$\Phi$ & $4.200^{\mathrm{a}}$ & $4.360(0.055)$ & 6.505 & 4 & ${ }^{* * *}$ \\
\hline \multicolumn{6}{|c|}{ 4: Entrance Channel } \\
\hline$S$ & $23.20(5.070)^{\mathrm{b}}$ & $19.40(2.191)^{\mathrm{c}}$ & 1.538 & 8 & $\mathrm{~ns}$ \\
\hline$N$ & $210.8(47.362)^{\mathrm{c}}$ & $172.0(46.530)^{\mathrm{c}}$ & 1.307 & 8 & $\mathrm{~ns}$ \\
\hline$H^{\prime}$ & $1.938(0.169)^{\mathrm{b}}$ & $1.780(0.400)^{\mathrm{C}}$ & 0.814 & 8 & ns \\
\hline$E$ & $0.621(0.018)^{b}$ & $0.602(0.120)^{\mathrm{c}}$ & 0.350 & 8 & $\mathrm{~ns}$ \\
\hline$B$ & - & $28.983(23.026)^{\mathrm{c}}$ & - & - & - \\
\hline$\% O M$ & $2.154(0.137)$ & $1.480(0.143)$ & 7.610 & 8 & ${ }^{* * *}$ \\
\hline$\Phi$ & $2.486(0.103)$ & $3.420(0.432)$ & 4.703 & 8 & ${ }^{* * *}$ \\
\hline \multicolumn{6}{|c|}{ 5: Oriental Bay } \\
\hline$S$ & $6.400(5.273)$ & $16.200(4.438)$ & 3.180 & 8 & ** \\
\hline$N$ & - & $67.200(23.059)$ & - & - & - \\
\hline$H^{\prime}$ & - & $1.860(0.350)$ & - & - & - \\
\hline$E$ & - & $0.672(0.079)$ & - & - & - \\
\hline$B$ & - & $55.902(26.457)$ & - & - & - \\
\hline$\% O M$ & - & $1.396(0.083)$ & - & - & - \\
\hline$\Phi$ & - & $2.200(0.122)$ & - & - & - \\
\hline \multicolumn{6}{|c|}{ 6: Queens Wharf } \\
\hline$S$ & $13.800(2.168)$ & $5.600(1.342)$ & 7.191 & 8 & $* * *$ \\
\hline$N$ & $33.000(8.396)$ & $12.000(3.808)$ & 5.093 & 8 & $* * *$ \\
\hline$H^{\prime}$ & $2.282(0.261)$ & $1.492(0.269)$ & 4.713 & 8 & ${ }^{* * *}$ \\
\hline$E$ & $0.871(0.068)$ & $0.872(0.075)$ & 0.022 & 8 & $\mathrm{~ns}$ \\
\hline$B$ & $12.820(8.361)$ & $14.883(8.342)$ & 0.391 & 8 & $\mathrm{~ns}$ \\
\hline$\% O M$ & $5.560(1.095)$ & $3.676(1.795)$ & 2.004 & 8 & $*$ \\
\hline$\Phi$ & $2.720(0.826)$ & $3.340(0.619)$ & 1.343 & 8 & ns \\
\hline
\end{tabular}


dency for replicates from Stns 3 and 6 to separate out. Cluster IV was solely composed of the 5 replicates from post-bloom Stn 5, while Cluster V was divisible into 2 groups composed of the pre- versus post-bloom samples from Stn 4.

\section{Subtidal sediment-percent organic matter}

Percent organic matter content of the sediment was typically in the range 3 to $7 \%$ for all stations, except Stn 4 where it was in the range 1.5 to $2.5 \%$ (Table 3 ). A significant increase in percent organic matter for pre- versus post-bloom sediment was observed at $\operatorname{Stn} 3$ ( $t=$ 18.492, p $<0.001$ ), and a significant decrease was observed at Stns 4 and $6(t=7.610, \mathrm{p}<0.001$ and $t=$ $2.004, \mathrm{p}<0.05$, respectively).

\section{Subtidal sediment-median phi}

Median particle size for all stations was typically in the phi range 2 to 4.5 (Table 3 ). A significant decrease in median phi (an increase in particle size) was observed at Stn 1, which was attributable to a small number of greywacke rock pebbles 20 to $30 \mathrm{~mm}$ in

Table 4. Numbers of species $(S)$, numbers of individuals $(N)$ and biomass $(B)$ (all standardised to per $0.1 \mathrm{~m}^{-2}$ grab) assessed at phylum level (numerically important groups only). -: no data

\begin{tabular}{|c|c|c|c|c|c|c|}
\hline $\begin{array}{l}\text { Stn, } \\
\quad \text { Period }\end{array}$ & Index & Polychaetes & Crustaceans & Echinoderms & Molluscs & Total all groups \\
\hline \multicolumn{7}{|c|}{ 1: Kaiwharawhara } \\
\hline \multirow[t]{3}{*}{ Pre-bloom } & $S$ & 4.60 & 2.40 & 0.60 & 2.40 & 10.20 \\
\hline & $N$ & 43.60 & 6.40 & 4.40 & 6.40 & 61.60 \\
\hline & $B$ & - & - & - & - & 14.47 \\
\hline \multirow[t]{3}{*}{ Post-bloom } & $S$ & 3.40 & 1.40 & 0.20 & 2.00 & 7.20 \\
\hline & $N$ & 12.80 & 10.20 & 1.40 & 24.60 & 49.20 \\
\hline & $B$ & 0.85 & 1.24 & 0.66 & 2.09 & 5.93 \\
\hline \multicolumn{7}{|c|}{ 2: Harbour Basin West } \\
\hline \multirow[t]{3}{*}{ Pre-bloom } & $S$ & 2.20 & 1.40 & 0.60 & 1.20 & 6.00 \\
\hline & $N$ & 15.20 & 22.60 & 15.60 & 4.60 & 59.60 \\
\hline & $B$ & - & - & - & - & 32.37 \\
\hline \multirow[t]{3}{*}{ Post-bloom } & $S$ & 0.80 & 0.60 & 0.00 & 0.60 & 2.60 \\
\hline & $N$ & 5.60 & 5.60 & 0.00 & 1.00 & 13.40 \\
\hline & $B$ & 1.14 & 0.97 & 0.00 & 3.59 & 6.54 \\
\hline \multicolumn{7}{|c|}{ 3: Harbour Basin East } \\
\hline \multirow[t]{3}{*}{ Pre-bloom } & $S$ & 10.00 & 2.00 & 1.00 & 3.00 & 17.00 \\
\hline & $N$ & - & - & - & - & - \\
\hline & $B$ & - & - & - & - & - \\
\hline \multirow[t]{3}{*}{ Post-bloom } & $S$ & 0.80 & 0.40 & 0.00 & 0.20 & 1.60 \\
\hline & $N$ & 2.40 & 2.00 & 0.00 & 0.20 & 4.80 \\
\hline & $B$ & 0.58 & 0.40 & 0.00 & 1.39 & 2.37 \\
\hline \multicolumn{7}{|c|}{ 4: Entrance Channel } \\
\hline \multirow{3}{*}{ Pre-bloom } & $S$ & 3.20 & 3.60 & 0.40 & 2.60 & 10.00 \\
\hline & $N$ & 67.60 & 124.00 & 2.80 & 15.00 & 276.40 \\
\hline & $B$ & - & - & - & - & - \\
\hline \multirow[t]{3}{*}{ Post-bloom } & $S$ & 2.20 & 4.00 & 0.60 & 2.80 & 9.80 \\
\hline & $N$ & 22.60 & 132.60 & 2.20 & 14.40 & 172.00 \\
\hline & $B$ & 1.04 & 2.98 & 11.81 & 13.01 & 28.98 \\
\hline \multicolumn{7}{|l|}{ 5: Oriental Bay } \\
\hline \multirow{3}{*}{ Pre-bloom } & $S$ & 0.60 & 0.20 & 0.60 & 2.00 & 3.60 \\
\hline & $N$ & - & - & - & - & - \\
\hline & $B$ & - & - & - & - & - \\
\hline \multirow[t]{3}{*}{ Post-bloom } & $S$ & 2.60 & 1.20 & 0.80 & 1.80 & 7.00 \\
\hline & $N$ & 43.80 & 4.20 & 2.60 & 11.00 & 67.20 \\
\hline & $B$ & 2.28 & 0.12 & 1.32 & 51.81 & 55.90 \\
\hline \multicolumn{7}{|c|}{ 6: Queens Wharf } \\
\hline \multirow[t]{3}{*}{ Pre-bloom } & $S$ & 3.00 & 0.60 & 0.60 & 2.40 & 7.00 \\
\hline & $N$ & 17.00 & 0.80 & 1.40 & 11.80 & 33.00 \\
\hline & $B$ & - & - & - & - & 12.82 \\
\hline \multirow[t]{3}{*}{ Post-bloom } & $S$ & 1.80 & 0.20 & 0.20 & 0.80 & 3.20 \\
\hline & $N$ & 4.80 & 4.40 & 0.80 & 1.60 & 12.00 \\
\hline & $B$ & 0.70 & 2.13 & 4.89 & 5.69 & 14.88 \\
\hline
\end{tabular}




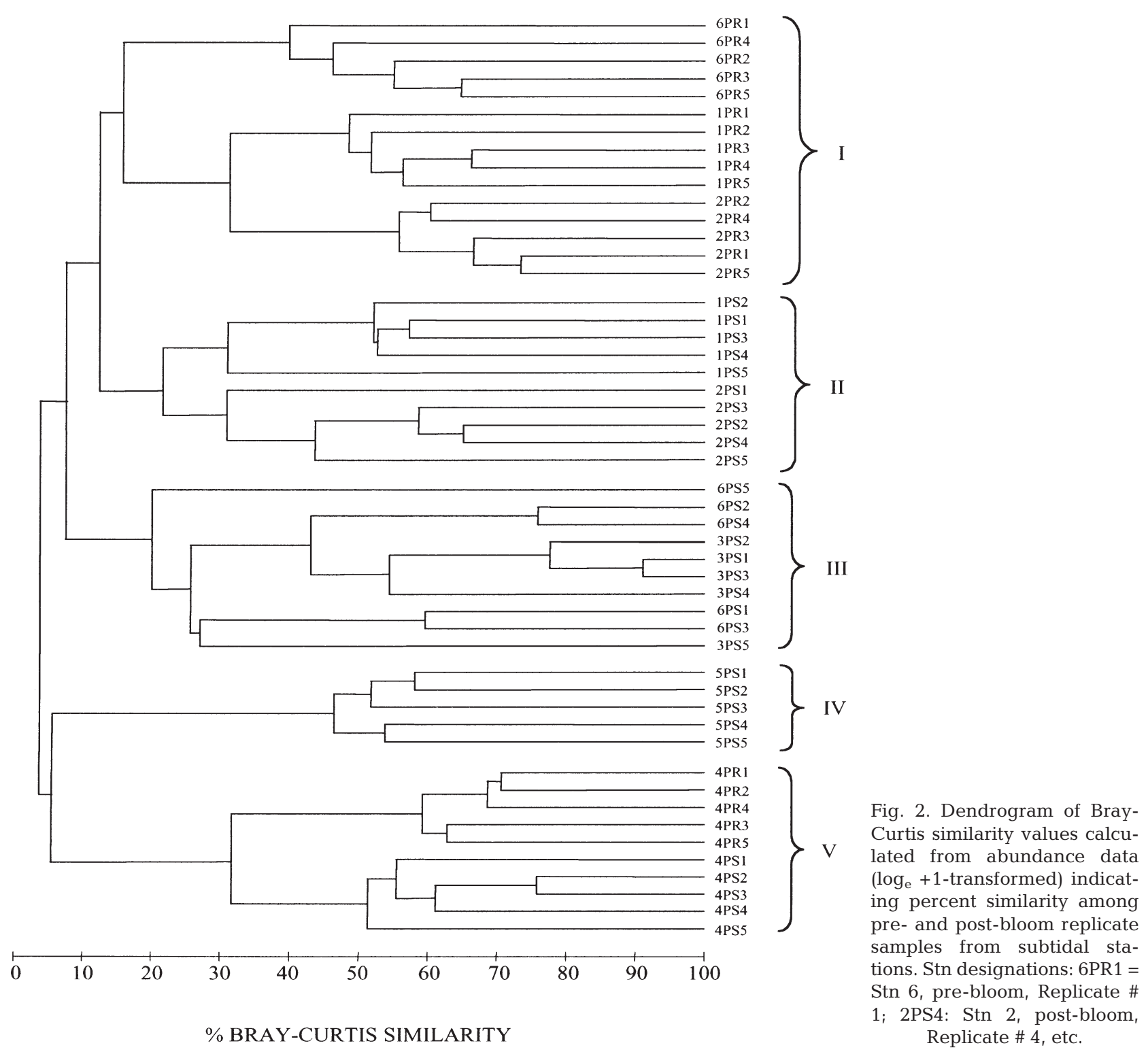

diameter, probably originating from dumping activity prior to 1984 . When these pebbles are excluded from the analysis, then the median phi value remains unchanged for the pre- versus post-bloom comparison (pre- vs post-bloom mean \pm SD, $2.660 \pm 1.476$ vs $2.680 \pm 0.769, t=0.0269, \mathrm{df}=8, \mathrm{p}>0.05)$. A significant increase in median phi value was observed at the predominantly silty Stns 2, 3 and 4 when pre- and postbloom values were compared $(t=4.433$, $\mathrm{p}<0.001$; $t=$ 6.505, $\mathrm{p}<0.001 ; t=4.703, \mathrm{p}<0.001$, respectively).

\section{Intertidal station}

At Stn 7, 12 macroalgal and 38 animal species were recorded pre-bloom (Wear 1997a). The high shore was dominated by the littorinid gastropods Eulittorina cincta and E. unifasciata which were common or very common, and the mid-shore by abundant small acorn barnacles Chamaesipho spp., topshells Melagraphia aethiops and limpets Cellana spp., which were common. Towards the lower part of the mid-shore, blue mussels Mytilus galloprovincialis were very common and dominated, and the catseye snail Turbo smaragdus was common. The cobbled substrate of the low shore was dominated by barnacles and blue mussel clumps, but much of the surface lacked macroalgal or animal life due to substrate mobility. Brown macroalgae (especially Carpophyllum maschalocarpum and Cystophora spp.) and red algae (Lithothamnion spp., Corallina officinalis, Gigartina spp.) dominated towards ELWS. The biota beneath cobbles was rich, with dominant 
Table 5. Summary table of station-by-station responses of 5 biological indices to the effects of the toxic algal bloom. $S$ : species richness; $N$ : number of individuals; $H^{\prime}$ : species diversity; $E$ : evenness; $B$ : biomass; $\Downarrow$ significant decrease; $\Uparrow$ significant increase; ns: no significant change - : no data to test

\begin{tabular}{|c|c|c|c|c|c|c|}
\hline \multirow[t]{2}{*}{ Stn } & \multirow{2}{*}{ Location } & \multicolumn{5}{|c|}{ Biological index } \\
\hline & & $S$ & $N$ & $H^{\prime}$ & $E$ & $B$ \\
\hline 1 & $\begin{array}{l}\text { Subtidal, } \\
\text { Northwest Harbour }\end{array}$ & $\Downarrow$ & ns & $\Downarrow$ & ns & $\Downarrow$ \\
\hline 2 & $\begin{array}{l}\text { Subtidal, } \\
\text { Northern Harbour }\end{array}$ & $\Downarrow$ & $\Downarrow$ & $\Downarrow$ & $\Uparrow$ & $\mathrm{ns}$ \\
\hline 3 & $\begin{array}{l}\text { Subtidal, } \\
\text { Northeast Harbour }\end{array}$ & $\Downarrow$ & - & $\Downarrow$ & $\Uparrow$ & - \\
\hline 4 & $\begin{array}{l}\text { Subtidal, } \\
\text { Southern Harbour }\end{array}$ & ns & ns & ns & $\Downarrow$ & - \\
\hline 5 & $\begin{array}{l}\text { Subtidal, } \\
\text { Northwest Harbour }\end{array}$ & $\Uparrow$ & - & - & - & - \\
\hline 6 & $\begin{array}{l}\text { Subtidal, } \\
\text { Northwest Harbour }\end{array}$ & $\Downarrow$ & $\Downarrow$ & $\Downarrow$ & $\mathrm{ns}$ & ns \\
\hline 7 & $\begin{array}{l}\text { Intertidal, } \\
\text { Northwest Harbour }\end{array}$ & $\Downarrow$ & $\Downarrow$ & - & - & - \\
\hline
\end{tabular}

and very common gastropod species being Melagraphia aethiops, T. smaragdus, amphipods and the false crab Petrolisthes elongatus. Limpets, Diloma spp., cariniferous polychaetes, the chiton Sipharochiton pelliserpentis and the crabs Hemigrapsus edwardsi and Heterozius rotundifrons were common. Mussel clumps contained abundant amphipods and P. elongatus, while the nereid polychaete Perinereis novaehollandiae was very common.

Following the bloom, we recorded 9 species of macroalgae and 23 animal species present over the transect, a $36 \%$ decrease in $S$ compared with pre-bloom levels. Jaccard's coefficient of similarity pre- versus post-bloom was 0.59 for the biota, 0.62 for the macroflora and 0.58 for the macrofauna. Most animal species were much decreased in $N_{\text {, }}$ and amphipods and polychaetes were absent from mussel clumps. Cariniferous polychaetes were few and errant polychaetes such as Perinereis novaehollandiae were absent. $N$ for gastropods and chitons was reduced by at least 1 order of magnitude, and 8 of 14 species recorded prebloom were absent. $N$ for crustaceans and echinoderms fell from common to few. Three species, Heterozius rotundifrons and Petrolisthes elongatus (Decapoda) and Patiriella regularis (Echinodermata) were represented by newly recruited juveniles which were very common or common, but no adults were seen. $N$ for blue mussels and barnacles were similar to those recorded prebloom.
Assigning arbitrary scores to each of the 4 relative abundance classes both pre- and post-bloom provided a total abundance score of 73 for the pre-bloom and 44 for the post-bloom macrofauna. $\chi^{2}$ analysis indicated a significantly higher pre- than post-bloom score $\left(\chi^{2}=\right.$ 7.188, $\mathrm{df}=1, \mathrm{p}<0.01)$. The contingency $\chi^{2}$ analysis indicated that there was no significant difference in the frequencies of species in the 4 relative abundance categories when the pre- and post-bloom situations were compared $\left(\chi^{2}=0.0871, \mathrm{df}=3, \mathrm{p}>0.05\right)$.

\section{DISCUSSION}

Because of the existence of pre-bloom baseline data, we are in the unusual position of being able to quantify the effects of a natural toxic bloom of Karenia brevisulcata at 7 different locations in Wellington Harbour. The only previous study of this type is from a small scale investigation of a subtropical intertidal estuarine area of Tampa Bay, where Simon \& Dauer $(1972,1977)$ reported that of the 22 most common pre-bloom species, only 5 were present immediately post-bloom. This Florida bloom indirectly resulted in decreases in $S$ of $77 \%$ and $N$ of $97 \%$. For comparative purposes, the maximum cell concentration recorded for Gymno-

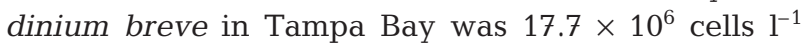
(Simon \& Dauer 1972), contrasted with a maximum concentration of $33 \times 10^{6}$ cells l$^{-1}$ recorded for $K$. brevisulcata in Wellington Harbour (Chang 1998). In common with the Tampa Bay bloom, there is no evidence

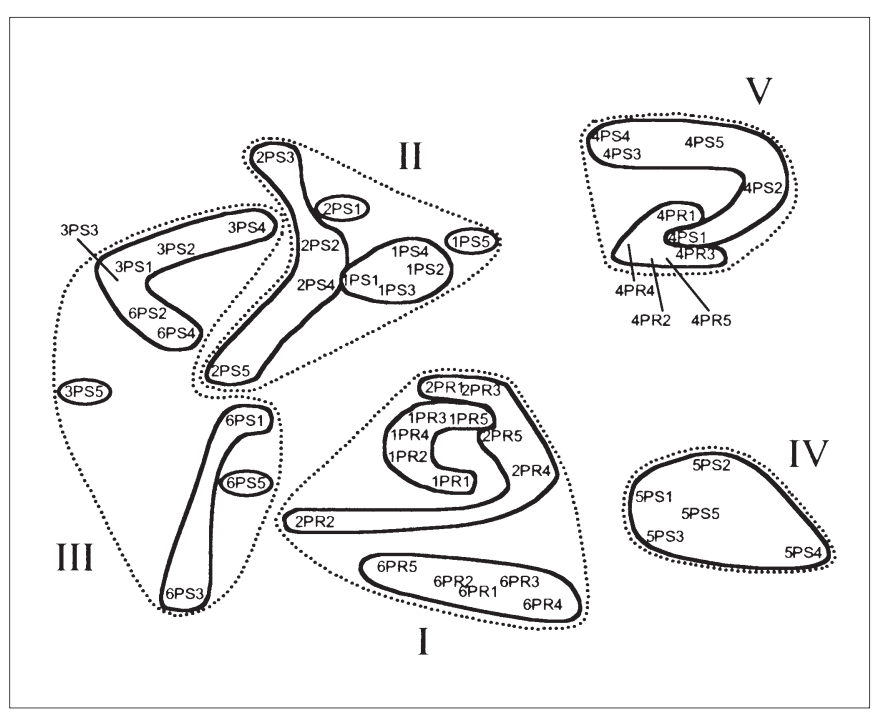

Fig. 3. MDS ordination (stress $=0.19$ ) of Bray-Curtis similarity values calculated from $\log _{e}(1+x)$ transformed abundance data indicating similarity among pre- and post-bloom replicate samples from subtidal stations. Dotted line: $20 \%$ similarity; continuous line: $40 \%$ similarity. 4 -digit code as in Fig. 2 
that the bloom in Wellington Harbour was anything other than a natural event. However, this is the first toxic bloom in the recorded history of Wellington Harbour, whereas there is a history of toxic blooms for Tampa Bay (Simon \& Dauer 1972). The mass invertebrate die-off in Tampa Bay was not caused directly by the toxic effect of the bloom, but resulted from anaerobic conditions created along a small area of the intertidal zone associated with the natural deposition and subsequent decomposition of dead fishes that had been killed directly by toxins (Simon \& Dauer 1972). Conversely, the mass biotic die-off in Wellington Harbour resulted directly from the toxin, and affected the whole harbour basin, from the deepest subtidal regions ( 20 $\mathrm{m} \mathrm{CD})$ up to the high intertidal. The present study is therefore the first report quantifying the direct effect of a natural toxic algal bloom on the benthic invertebrates of a large $\left(\sim 85 \mathrm{~km}^{2}\right)$ temperate marine ecosystem.

Sediment analyses of percent organic matter and median phi indicate that a number of statistically significant changes occurred during the pre- to postbloom period (Table 3). However, we do not believe that these changes have had a significant influence on the resident biota of individual stations. The significant decrease in median phi size at Stn 1 is solely attributable to the presence of a small number of large pebbles. When these were removed from the analysis there was no significant difference in median phi at this station, pre- versus post-bloom. The ecological impact of these isolated pebbles is likely to be negligible, because the faunal composition of the area would be determined by the percent organic matter content of the sediment and the predominant sediment type (which is fine sand), both of which remained unchanged pre- to post-bloom. Also, increases in median phi values at Stns 2, 3 and 4, although statistically significant, are all within a narrow range and are therefore unlikely to have had an ecological impact (Stns 2 and 3 changed within the range of very fine sand to silt, and Stn 4 within the range of medium to fine sand).

The effect of the toxic bloom on Wellington Harbour is best highlighted by the following biological data (Table 5): $S$ decreased at 6 stations and increased at 1 station, $N$ decreased at 4 of 4 stations, $H^{\prime}$ decreased at 5 of 5 stations, $E$ decreased at 2 and increased at 2 stations, and $B$ decreased at 2 of 3 stations. Data from the 4 stations closest to the centre of the bloom concentration (Stns 1, 2, 4 and 6) indicated a significant decrease in $S$ from mean values of 18.8 pre- bloom to 11.7 postbloom, a non-significant decrease in $N$ from 91 prebloom to 76 post-bloom, a significant decrease in $H^{\prime}$ from 2.268 pre-bloom to 1.792 post-bloom, and a nonsignificant increase in $E$ from 0.788 pre-bloom to 0.806 post-bloom. These data indicate that the Karenia bre- visulcata bloom of late summer 1998 resulted in a mass die-off of the subtidal benthic invertebrates over a large area of Wellington Harbour, as well as of the flora and fauna at 1 intertidal location studied. High levels of variability among replicate samples both pre- and post-bloom have reduced the statistical significance of some of the data, in particular, for estimates of $N$ and $B$. This variability reflects the naturally patchy structure of the subtidal communities being investigated, but does not obscure the bigger picture of a large-scale and indiscriminate natural die-off within Wellington Harbour.

The impact of the toxic bloom upon the biota of Wellington Harbour varied according to station location, and is related to and best explained in terms of the properties (physical, geological, chemical, etc) of each station. Stns 1, 2, 3 and 6 (Kaiwharawhara, Harbour Basin West, Harbour Basin East and Queens Wharf; see Fig. 1) are all characterised by medium/fine sand to silt (phi range of 2.5 to 4.5 ), high levels of sediment organic matter (4 to $7 \%$ ), and low levels of wave and current energy on the bottom. These stations are located in the northern half of the harbour, where the impact of the toxic bloom on the fauna was most pronounced, with all stations exhibiting reductions in $S, N$ and $B$ (except Stn 6 which showed little change in $B$ ). The division of these stations into 1 separate cluster of pre-bloom and 2 separate clusters of post-bloom samples reflects a temporal difference, that is, the effect of the bloom upon community structure. These clusters are independent of date of collection, and are unlikely to reflect natural seasonal variation because pre-bloom data from all but 1 station were collected summer to early fall, and the post-bloom data were from late fall (early May). In New Zealand's cool temperate hydrological regime, differences in water temperature are not extreme over that period. There is also, however, a significant spatial component to the clustering, in that the pre-bloom replicates for Stns 1 and 2 cluster most closely together (away from pre-bloom Stn 6), and this same pattern is maintained in the post-bloom samples. SCUBA diving observations at these stations immediately post-bloom revealed a fine, khaki-coloured layer covering the sediment, which we considered to be the settling-out of the bloom itself. This was the first time that such a khaki layer had been observed by us over many years of diving in the harbour. There was no evidence of recent bioturbation, either in terms of ambulatory tracks across the substrate or movement of subsurface sediment to the surface resulting from normal feeding and/or burrowing activity. We suggest that the profound impact of the bloom on the invertebrates at these stations is related to the low energy input, as there is little wave or current action at these sites, which are some of the deepest areas of the harbour. 
The bloom was able to settle out and concentrate through the deep water column and 'smother' the substrate, so influencing the infaunal communities at these stations. Because of the weak water movement at these stations, the concentrated toxin would have remained static in one location for a long period, and would therefore have had a greater opportunity to kill the infaunal community. Sampling carried out immediately post-bloom revealed that the few surviving organisms were typically the larger, deeper burrowing species such as the shrimp Jaxea novaezealandiae, large polychaetes such as Asychis trifilosa, Polychaete sp. $B$, and Nephtyidae sp. $B$, and the mud crab Macrophthalmus hirtipes. Small surface or near-surface dwelling animals such as the bivalve Theora lubrica, all amphipod species, the echinoid Echinocardium caudatum, and the ophiuroid Amphiura rosea, all of which were abundant pre-bloom, were absent post-bloom. Smaller individuals of larger species of the major phyla which tend to burrow less deeply were also absent from post-bloom samples. Evenness $(E)$ remained unchanged at Stns 1 and 6, but increased significantly at Stns 2 and 3, here indicating a reduction in numerical dominance by certain species. Thus, one outcome of the bloom at Stns 2 and 3 was to make the numbers of surviving individuals per species fewer (often < 10) and more equally distributed among species compared with the pre-bloom situation.

The multivariate analyses recognised a cluster composed of the 5 replicates from the post-bloom survey of Stn 5 (no pre-bloom data were available for this station). This site is defined by a biological community which is substantially different from those of all other stations, either pre- or post-bloom, indicating that this is a separation based on spatial rather than temporal differences. Stn 5 (Oriental Bay, Fig. 1) is exposed to the prevailing northerly winds, and because it is a shallow ( $2 \mathrm{~m}$ depth) location, wave energy input is high. It is characterised by medium sand (phi 2.2) and a low percent organic matter content (1.4\%). The absence of detailed replicated pre-bloom data for this site precluded us from quantifying the full effects of the bloom. However, $S$ increased 3.6 to 7.0 species per grab sample pre- versus post-bloom, a change that is attributable to large increases in $S$ among the polychaetes and crustaceans. These changes are at odds with the reductions recorded for other stations. The biological explanation for changes at this station remains unknown, but may be related to the shallowness of the site and the high level of water exchange and mixing which, together, prevented the bloom from deleteriously affecting the biota despite the geographical proximity of this station to the centre of the bloom. However, while these factors may explain why the site was not negatively affected, they do not explain why $S$ increased significantly.
The multivariate analyses indicate that the 10 preand post-bloom replicates from Stn 4 form a distinct cluster from all other samples and can therefore be considered to be biologically distinct. This is because Stn 4 is spatially removed from, and as a consequence experiences different hydrographical conditions from, all other stations. The effect of the bloom upon community structure at Stn 4 is clearly apparent in the separation of the pre- from the post-bloom replicates. Stn 4 (Entrance Channel, see Fig. 1) is at intermediate depth $(\sim 11 \mathrm{~m})$, and characterised by slightly coarser sediments (phi range 2.5 to 3.4 , medium to fine sand but no silt) and a lower percent organic matter content (1.5 to $2.1 \%$ ). The substrate exhibits pronounced ripples and experiences occasional strong current and wave energy, resulting in substantial sediment movement (Carter 1977). Although $N, S, H^{\prime}$ and $E$ were all reduced at this station post-bloom, none of these changes was statistically significant. These 4 decreases suggest that although the bloom impacted negatively upon the biological community at this station, this was not as profound as at Stns 1, 2, 3 and 6. There are 2 likely explanations for this. First, the site is geographically furthest away from the central harbour basin where the bloom was at its greatest concentration and would therefore have experienced the least effect of all sites studied. Second, this site experiences the greatest amount of tidal exchange of all our sites. Being located in the entrance channel to the Harbour, Stn 4 receives a constant, and at times, high level of water flow and mixing, as the incoming tide brings seawater from Cook Strait into Wellington Harbour (Maxwell 1956). The polychaetes were affected most significantly, with reductions in $S$ and $N$, whereas the crustaceans, echinoderms and molluscs registered only small changes (increases and decreases) in $S$ and $N$, indicating that these groups were largely unaffected by the toxic bloom. The non- significant decrease in $E$ at this site mirrors these large changes among the polychaetes and the very small change in the 3 other groups. The impact of the bloom was therefore minimal at this site because of the site's location away from the centre of bloom activity and its hydrological conditions which are different from all other stations.

Stn 7 is the intertidal location at Oriental Bay (a shoreward extension of Stn 5, see Fig. 1) and is very different from the other stations in all its properties. The absence of detailed pre-bloom data for this station precludes us from quantifying the full effects of the bloom. However, $S$ decreased from 50 (12 macroflora and 38 macrofauna) to 32 (9 macroflora and 23 macrofauna) pre- versus post- bloom. Macroalgal species which were present pre-bloom, but absent postbloom, included Enteromorpha intestinalis (Chlorophyta), Halopteris funicularis (Phaeophyta), and Gelid- 
ium pusilum and Porphyra columbina (Rhodophyta). Gigartina sp. (Rhodophyta) was absent pre-bloom but present post-bloom. The loss of 4 macroalgal species could be due to seasonal factors, but the bloom clearly affected the intertidal macrofauna with the loss of 16 species or $>40 \%$ of all animal species. The significant reduction in total abundance score from 73 pre-bloom to 44 post-bloom emphasises the impact of the bloom upon the intertidal macrofauna. The relative proportions of species in the 4 different abundance categories did not change significantly as a result of the bloom, indicating that species from all 4 categories were affected by the bloom. In biological terms this means that all categories of species, from the most abundant to the rarest, were affected equally (in relative terms) by the bloom.

In conclusion, the toxic algal bloom of Karenia brevisulcata that occurred in Wellington Harbour in late summer 1998, had a widespread and profound impact upon the biological communities at a number of different locations. The low-energy silty environment of the central Harbour basin was impacted more severely than the shallower low-energy areas subject to strong tidal flows or wind-induced turbulence. This research is on-going, and we are monitoring the sequence of recolonisation at the subtidal stations. The scale of this 'natural' experiment is unprecedented, and has allowed us to quantify the effects of a large-scale toxic algal bloom upon the community structure and dynamics of a temperate harbour ecosystem.

Acknowledgements. We thank Kathryn Botherway, Nicola Chong, Kerstin Kröger, Joanne Long, Robert Williamson, and Susanna Wood for help in the field and/or laboratory. This research was supported by funding from The Vice Chancellor's Fund, the Internal Grants Committee, and the Island Bay Marine Laboratory, all of Victoria University of Wellington.

\section{LITERATURE CITED}

Anderlini VC, Wear RG (1995) Ecological survey of proposed dredge sites at Queens Wharf Wellington Harbour. Report prepared for Port Wellington Ltd, August 1995, Wellington Booth JD (1975) Seasonal and tidal variations in the hydrology of Wellington Harbour. NZ J Mar Freshw Res 9:333-354

Carr MR (1996) PRIMER user manual. Plymouth Marine Laboratory, Plymouth

Carter L (1977) Sand transport, Wellington Harbour entrance, New Zealand. NZ J Geol Geophys 20:335-351

Carter L, Lewis K (1995) Variability of the modern sand cover

Editorial responsibility: Otto Kinne (Editor),

Oldendorf/Luhe, Germany on a tide and storm driven inner shelf, south Wellington, New Zealand. NZ J Geol Geophys 38:451-470

Carter L, Mitchell JS (1985) Stability of an artificially nourished beach, Balaena Bay, Wellington Harbour, New Zealand. NZ J Mar Freshw Res 19:535-552

Chang FH (1998) Aquaculture Update 21, NIWA, Wellington

Chang FH (1999a) Gymnodinium brevisulcatum sp. nov. (Gymnodiniales, Dinophyceae), a new species isolated from the 1998 summer toxic bloom in Wellington Harbour, New Zealand. Phycologia 38:377-384

Chang FH (1999b) Aquaculture Update 23, NIWA, Wellington

Clarke KR, Warwick RM (1994) Change in marine communities: an approach to statistical analysis and interpretation. Plymouth Marine Laboratory, Plymouth

Daugbjerg N, Hansen G, Larsen J, Moestrup Ø (2000) Phylogeny of some of the major genera of dinoflagellates based on ultrastructure and partial LSU rDNA sequence data, including the erection of three new genera of unarmoured dinoflagellates. Phycologia 39:302-317

Haddon M, Wear RG (1993) Ecological survey of proposed dredge sites in Wellington Harbour. Coastal Marine Research Unit Report 22, Victoria University of Wellington

Heath RA (1977) Circulation and hydrology of Wellington Harbour. Oceanographic Summary 12, NZOI Wellington

Maxwell BE (1956) Hydrobiological observations for Wellington Harbour. Trans R Soc N Z 83:493-503

Simon JL, Dauer DM (1972) A quantitative evaluation of redtide induced mass mortalities of benthic invertebrates. Environ Lett 3:229-234

Simon JL, Dauer DM (1977) Reestablishment of a benthic community following natural defaunation. In: Coull BC (ed) Ecology of marine benthos. The Belle W Baruch Library in Marine Science, University of South Carolina Press, Columbia, SC, p 139-154

Sokal RR, Sneath PHA (1963) Principles of numerical taxonomy. WH Freeman \& Co, San Francisco

van der Linden WJM (1967) A textural analysis of Wellington Harbour sediments. N Z J Mar Freshw Res 1:26-37

Warwick RM (1993) Environmental impact studies on marine communities: pragmatical considerations. Aust J Ecol 18: $63-80$

Warwick RM, Clarke KR (1993) Comparing the severity of disturbance: a meta-analysis of marine macrobenthic community data. Mar Ecol Prog Ser 92:221-231

Wear RG (1997a) Oriental Bay beach project-marine ecological survey. Report prepared for Ackroyd Walshe Ltd, March 1997, Wellington

Wear RG (1997b) Oriental Bay breakwater construction and beach refurbishment proposal: marine ecological survey. Report prepared for Ackroyd Walshe Ltd, August 1997, Wellington

Wear RG, Anderlini VC (1995) Ecological survey of proposed and previous sediment relocation sites in Wellington Harbour. Coastal Marine Research Unit Report 26, Victoria University of Wellington

Wear RG, Anderlini VC, Anderson SH (1990) Proposed sewage outfall and pipeline in Wellington Harbour. Coastal Marine Research Unit Report 15, Victoria University of Wellington

Submitted: May 30, 2000; Accepted: January 3, 2001

Proofs received from author(s): August 2, 2001 